\title{
Prediction Models of Albumin Renal Excretion in Type 2 Diabetes Mellitus Patients
}

\author{
AMORIN REMUS POPA ${ }^{1,2}$, CLAUDIA TEODORA JUDEA PUSTA ${ }^{1,2 *}$, COSMIN MIHAI VESA ${ }^{1,2 *}$, SIMONA BUNGAU ${ }^{1}$, \\ CAMELIA LIANA BUHAS ${ }^{1,2}$, CRISTIAN SAVA ${ }^{1}$, IOANA ALINA DIMULESCU (NICA) ${ }^{3}$, DANA CARMEN ZAHA ${ }^{1,2}$, CRISTIANA BUSTEA ${ }^{1,2}$ \\ ${ }^{1}$ University of Oradea, Faculty of Medicine and Pharmacy, 101 Decembrie Sq., 410073, Oradea, Romania \\ 2.Clinical County Emergency Hospital of Oradea, 65 Gheorghe Doja Str., 410169, Oradea, Romania \\ ${ }^{3}$ Politehnica University of Bucharest, Faculty of Applied Chemistry and Materials Science, 1-7 Gh. P. Polizu Str., 011061, Bucharest, \\ Romania
}

\begin{abstract}
Microalbuminuria is a cardiovascular risk factor in type 2 diabetes mellitus patients. It is very important to know which the predictor factors for albuminuria are, because these elements may be influenced by pharmacological measures. In our study we propose three models for the prediction of albumin glomerular excretion in a group of 446 type 2 diabetes mellitus patients: the clinical-biochemical model, the pharmacological model, and the integrative model that reunites the two models. In the clinical-biochemical model, albumin excretion was statistically significant influenced by HbAlc (positive correlation) and blood pressure (positive correlation). In the pharmacological model, albumin excretion was influenced by angiotensin converting enzyme inhibitors or angiotensin II receptor blockers treatment (negative correlation). In the integrative model, the factors were HbAlc (positive correlation), diastolic blood pressure (positive correlation), angiotensin converting enzyme inhibitors or angiotensin II receptor blockers treatment (negative correlation) and statins treatment (negative correlation). The prevalence of microalbuminuria was $16.14 \%$. Patients with microalbuminuria had statistically significant higher values of HbAlc, systolic blood pressure, diastolic blood pressure, triglycerides and lower values of HDL-cholesterol. A low glucose control was the most important risk factor for an increased albumin glomerular elimination. The importance of our study consists in the fact that all the elements that predict albuminuria can be influenced: HbAlc, blood pressure, therapy with angiotensin converting enzyme inhibitors or angiotensin II receptor blockers and statins.
\end{abstract}

Keywords: albuminuria, type 2 diabetes mellitus, endothelial dysfunction, ACEI, ARB, statins

Microalbuminuria represents the urinary elimination of more than $30 \mathrm{mg} /$ day of albumin or a urine albumin/ creatinine ratio greater than $30 \mathrm{mg} / \mathrm{g}$ [1]. Microalbuminuria is a predictor of cardiovascular disease both in patients with type 1 diabetes mellitus and type 2 diabetes mellitus [2]. The association between the increased level of albumin excretion and cardiovascular disease, myocardial infarction or stroke, is the presence of a common causality and this causality is represented by the endothelial alterations produced by the diabetic environment [3-5]. The diabetic environment is the presence of a metabolic state where hyperglycemia, obesity and insulin resistance generate a series of modifications with significant impact on all the tissues: increased level of inflammation, oxidative stress, high blood pressure, atherogenic dyslipidemia, hypercoagulability [5,6]. All these elements contribute to endothelial alteration or endothelial dysfunction, and the all the changes generalized over the entire endothelial system [1].

Microalbuminuria is also a predictor of diabetic nephropathy, which represents, in developed countries, the first cause of end stage renal disease [7]. The morphologic changes in the glomeruli affected by diabetic nephropathy include capillary basement membrane thickening, diffuse mesangial sclerosis, and nodular glomerulosclerosis [8]. Concentric layers of hyaline material deposition, composed predominantly of type IV collagen, is the main morphologic change in thickened basal lamina separating the endothelial cells from the surrounding tissue. In addition, and increased amount of fibronectin is synthesized while there is a decreased synthesis of the heparan sulfate proteoglycan. These changes occur in all vascular tissue of diabetic patients and are a part of generalized diabetic microangiopathy. Diffuse mesangial sclerosis consists of diffuse increase in mesangial matrix by PAS positive depositions, is associated with the overall thickening of the glomerular basement membrane and correlates with increasing proteinuria. Nodular glomerulosclerosis consists of ovoid or spherical nodules of matrix situated in the periphery of the glomerulus and commonly it does not involve all the lobules in the individual glomerulus. Nodular glomerulosclerosis is not specific for diabetes but it's presence implies, in most instances, the progression to renal failure.

The mechanisms that determine the renal damage in type 1 and type 2 diabetes are related to hyperglycemia, being very complex and include: increased oxidative stress, increased production of vascular endothelial growth factors that alters the permeability of the glomerular capillaries, increased production of cytokines such as TNF- $\alpha$ or IL- 6 and adipokines such as leptin that increase the expression of adhesion molecules and increase the permeability of the glomerular membrane [2]. The risk factors for microalbuminuria presence in diabetes mellitus patients are multiple and include: hypertension [9,10], low glycemic control [11,12], serum creatinine, triglycerides, smoking $[13,14]$. Albumin/ creatinine ratio has been validated as a method for the screening of microalbuminuria [11]. Patients that suffer from type 2 diabetes mellitus should be screened annually for the presence of microalbuminuria from the moment of diagnosis as recommended by the American Diabetes Association [11]. A good glycemic control and monitoring the blood pressure values are mandatory in diabetic patients. There are also pharmacological factors that 
protect against the apparition of microalbuminuria in diabetes patients, the most prominent being angiotensin converting enzyme inhibitors (ACEI) or angiotensin II receptor blockers (ARB) treatment. ACEI determines a reduction of microalbuminuria both in normotensive and hypertensive patients suffering of diabetes mellitus and reduces the progression to end stage renal disease [15]. ACE inhibitors beneficial favorable effects on renal function in diabetic renal disease are likely attributable to the systemic and renal hemodynamic changes; they blunt the intrarenal arteriolar effects of Ang II, leading to dilation of efferent arterioles, reduction on glomerular capillary pressure and the attendant glomerular hypertension. Furthermore, these agents reduce the glomerular permeability, leading to a lower urinary albumin excretion [16]. ARBs act by blocking Ang II type 1 receptors (AT receptors). This AT blockade may lead to further increase in synthesis of Ang II which binds to intrarenal Ang II type 2 (AT, receptors), resulting in decreased blood pressure and reduced renal interstitial fibrosis [17].

It is important to know the risk factors and protective factors for microalbuminuria diabetes mellitus patients in order to apply the measures that can be taken to reduce the intensity of the process and improve endothelial dysfunction. In our study we investigated the prevalence and risk factors for microalbuminuria in a cohort of 446 patients with type 2 diabetes mellitus. We constructed three models for prediction of microalbuminuria: the clinical biochemical model, the pharmacological model and the integrative model in order to determine which components of the model have a statistically significant association with albuminuria intensity.

\section{Experimental part}

\section{Material and method}

We included in our study 446 patients with type 2 diabetes mellitus from the Clinical County Emergency Hospital of Oradea. The inclusion criteria in the study were: patients between 18 and 65 years old; patients with type 2 diabetes mellitus; patients that in the past six months did not have any modification in the treatment for diabetes mellitus, hypertension, and dyslipidemia; patients that gave their consentfor the participation in the study. The exclusion criteria were: patients with type 1 diabetes mellitus or other forms of diabetes mellitus, patients with a low glycemic control $\mathrm{HbAlce} \geq 10 \%$, patients with severe hypertension $>180 / 110 \mathrm{mmHg}$, patients with other kidney diseases that can determine an increased glomerular excretion of proteins (chronic glomerulonephritis, chronic pyelonephritis, etc.), patients with urinary infection.

Patients that presented to the Ambulatory of the Clinical County Emergency Hospital of Oradea for diabetes medication prescription in the period 01 September -01 December 2018 were considered for the inclusion in the study. All patients were explained the content of the study and signed a written consent. The research was conducted according to the principles of the Helsinki Declaration and with the approbation of the Ethics Commission of the Faculty of Medicine and Pharmacy of Oradea.

For each patient we performed the anamnesis, physical exam, medical history evaluation and the therapeutic regimens that the patient followed. Blood pressure was measured, and the body-mass index was calculated. Laboratory work-up was performed including: serum creatinine, HbAlc, total cholesterol, LDL-cholesterol, HDLcholesterol, triglycerides. We also determined the albumin/ creatinine ratio in a spot urine sample. Microalbuminuria was defined as an albumin/creatinine ratio between $30 \mathrm{mg} /$ $\mathrm{g}$ and $300 \mathrm{mg} / \mathrm{g}$ in a spot urine sample. We determined if the patient was under one of these therapies: ACEI or ARB, spironolactone, calcium channel blockers, beta blockers, diuretics, statins, niacin, fibrates, insulin therapy or oral antidiabetic therapy. After applying the inclusion and exclusion criteria, 446 patients remained in the study.

The models that we proposed for the prediction of microalbuminuria were constructed by multiple linear regression. In every model we included different variables based on the assumption that the constellation of the included factors can influence the intensity of glomerular albumin filtration. The clinical-biochemical model included the following variables: age, gender, glomerular filtration rate, $\mathrm{HbAlc}$, BMI, systolic blood pressure, diastolic blood pressure, total cholesterol, HDL-cholesterol, LDLcholesterol, triglycerides. The pharmacological model included the presence or absence of treatment with the following medications: ACEI or ARB, spironolactone, calcium channel blockers, beta blockers, diuretics, statins, niacin, fibrates, and insulin therapy. The integrative included all the variables enumerated in the two models above. The statistical analysis of data was done with the help of the Biostat software. A value of $p<0.05$ was considered statistically significant.

\section{Results and discussions}

Table 1 presents the characteristics of the included patients.

The prevalence of microalbuminuria in our included patients was $16.14 \%$. In patients with microalbuminuria the level of HbAlc was statistically significant higher than in patients without microalbuminuria ( $7.34 \pm 1.57$ vs. $6.68 \pm 1.01, p<0.01$ ), the prevalence of hypertension was statistically significant higher ( $93.05 \%$ vs. $75.4 \%, p<0.01)$, the value of systolic blood pressure was statistically significant higher $(141.29 \pm 13.97 \mathrm{mmHg}$ vs. $128.52 \pm$ $15.05 \mathrm{mmHg}$ ), the value of diastolic blood pressure was statistically significant higher $(79.87 \pm 10.81 \mathrm{mmHg}$ vs. $74.13 \pm 8.13 \mathrm{mmHg}$ ), the value of $\mathrm{HDL}$-cholesterol was statistically significant lower $(41.08 \pm 12.10 \mathrm{mmHg}$ vs. $46.66 \pm 12.95 \mathrm{mmHg}, p<0.01$ ), the value of triglycerides was statistically significant higher $(191.84 \pm 126.39 \mathrm{mmHg}$ vs. $143.75 \pm 85.75 \mathrm{mmHg}, p<0.01$ ) (Table 1). The presence of ACEI or ARB treatment was statistically significanthigher in patients without microalbuminuria than in patients with microalbuminuria (fig. 2).

In the clinical-biochemical model for prediction of albuminuria in type 2 diabetes patients, the factors that influenced statistically significant the excretion of albumin were $\mathrm{HbAlc}$ (coefficient $=8.60$, positive correlation), the value of systolic blood pressure (coefficient $=0.42$, positive correlation), the value of diastolic blood pressure (coefficient $=1.25$, positive correlation). A positive

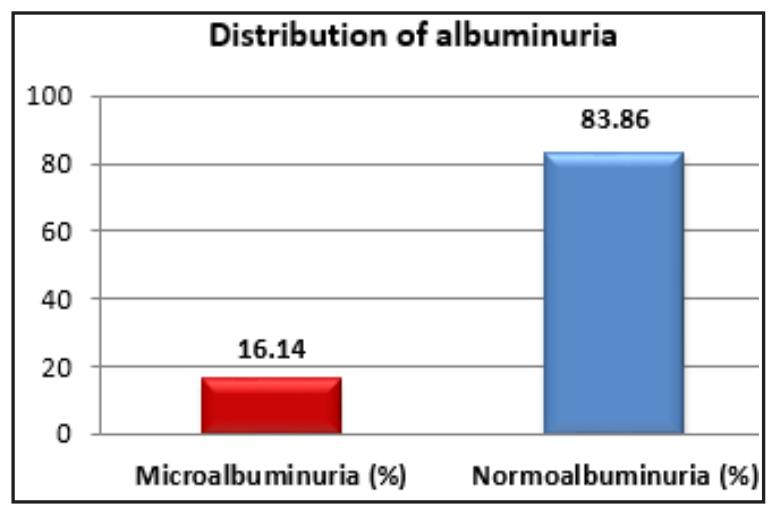

Fig. 1. The prevalence of the microalbuminuria 


\begin{tabular}{|c|c|c|c|c|}
\hline Parameter & $\begin{array}{c}\text { Microalbuminuria } \\
\text { Albumin/Creatinine } \\
\text { ratio } \geq 30 \mathrm{mg} / \mathrm{g} \text { and }<300 \mathrm{mg} / \mathrm{g} \\
(\mathrm{n}=72)\end{array}$ & $\begin{array}{l}\text { Normoalbuminuria } \\
\text { Albumin/Creatinine } \\
\text { ratio }<30 \mathrm{mg} / \mathrm{g}(\mathrm{n}=374)\end{array}$ & $\mathrm{p}$ & \multirow{25}{*}{$\begin{array}{c}\text { Table } 1 \\
\text { CHARACTERISTICS OF THE } \\
\text { INCLUDED PATIENTS }\end{array}$} \\
\hline Age (years) & $63.59 \pm 7.91$ & $62.45 \pm 7.94$ & 0.26 & \\
\hline Sex $(\%)$ Men & 83.33 & 72.99 & 0.06 & \\
\hline HbAlc (\%) & $7.34 \pm 1.57$ & $6.68 \pm 1.01$ & 20.01 & \\
\hline Diabetes duration (years) & $5.8 \pm 2.3$ & $5.3 \pm 2.5$ & 0.11 & \\
\hline Creatinine $(\mathrm{mg} / \mathrm{dL})$ & $0.99 \pm 0.12$ & $0.96 \pm 0.12$ & 0.05 & \\
\hline GFR $\left(\mathrm{mL} / \mathrm{min} / 1.73 \mathrm{~m}^{2}\right)$ & $76.98 \pm 7.97$ & $78.41 \pm 7.72$ & 0.15 & \\
\hline Albumin/ creatinine ratio $(\mathrm{mg} / \mathrm{g})$ & $119.45 \pm 103.16$ & $6.78 \pm 6.29$ & $<0.01$ & \\
\hline Hypertensive (\%) & 93.05 & 75.4 & $<0.01$ & \\
\hline $\mathrm{BMI}\left(\mathrm{kg} / \mathrm{m}^{2}\right)$ & $33.19 \pm 5.13$ & $32.28 \pm 5.79$ & 0.26 & \\
\hline Systolic blood pressure (mm Hg) & $141.29 \pm 13.97$ & $128.52 \pm 15.05$ & $<0.01$ & \\
\hline Diastolic blood pressure ( $\mathrm{mm} \mathrm{Hg}$ ) & $79.87 \pm 10.81$ & $74.13 \pm 8.13$ & $<0.01$ & \\
\hline Total cholesterol $(\mathrm{mg} / \mathrm{dL})$ & $167.73 \pm 37.43$ & $171.93 \pm 36.05$ & 0.36 & \\
\hline LDL-cholesterol (mg/dL) & $89.65 \pm 29.18$ & $95.75 \pm 28.15$ & 0.09 & \\
\hline HDL-cholesterol (mg/dL) & $41.08 \pm 12.10$ & $46.66 \pm 12.95$ & $<0.01$ & \\
\hline Triglycerides (mg/dL) & $191.84 \pm 126.39$ & $143.75 \pm 85.75$ & $<0.01$ & \\
\hline ACEI or ARB $(\%)$ & 23.61 & 39.03 & 0.01 & \\
\hline Spironolactone (\%) & 1.38 & 2.13 & 0.67 & \\
\hline Calcium channel blockers (\%) & 22.22 & 14.97 & 0.12 & \\
\hline Beta blockers (\%) & 20.83 & 12.29 & 0.05 & \\
\hline Diuretics (\%) & 27.77 & 27.27 & 0.93 & \\
\hline Statins (\%) & 65.27 & 62.6 & 0.67 & \\
\hline Niacin $(\%)$ & 9.72 & 6.95 & 0.28 & \\
\hline Fibrates (\%) & 9.71 & 9.35 & 0.92 & \\
\hline Insulin therapy (\%) & 20.83 & 18.76 & 0.68 & \\
\hline
\end{tabular}

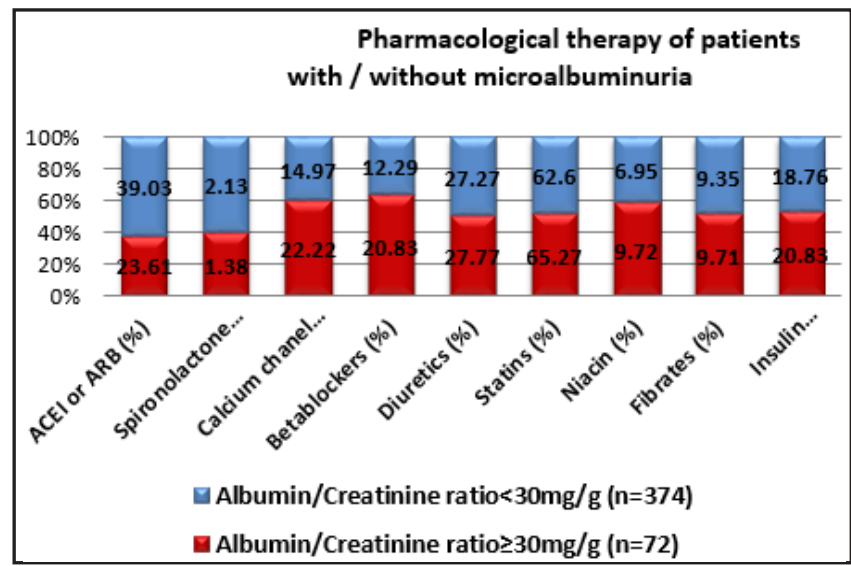

Fig. 2. The pharmacological treatment in patients with and without microalbuminuria

correlation means that higher values of the influencing factor correspond to a higher glomerular excretion of albumin.

In the pharmacological model for prediction of albuminuria in type 2 diabetes patients, the factor that influenced statistically significant the excretion of albumin was the presence of ACEl or ARB treatment (coefficient= 17.28). The correlation is negative, meaning that a higher prevalence of ACEI or ARB treatmentcorresponds to lower levels of glomerular albumin excretion.

In the integrative model for prediction of albuminuria, the factors that influenced statistically significant the glomerular excretion of albumin were as follows: $\mathrm{HbAlc}$ (coefficient $=10.05$ ), diastolic blood pressure (coefficient $=1.16$ ), ACEI or ARB treatment (coefficient=-14.61), and statins treatment (coefficient=-12.30). Using simple linear regression $\mathrm{HbAlc}$ had the most important impact on the albumin excretion $(p<0.001)$ (Figure 3$)$.

\section{Scatter Diagram (Predicted Y, Albuminuria vs. HbA1c)}

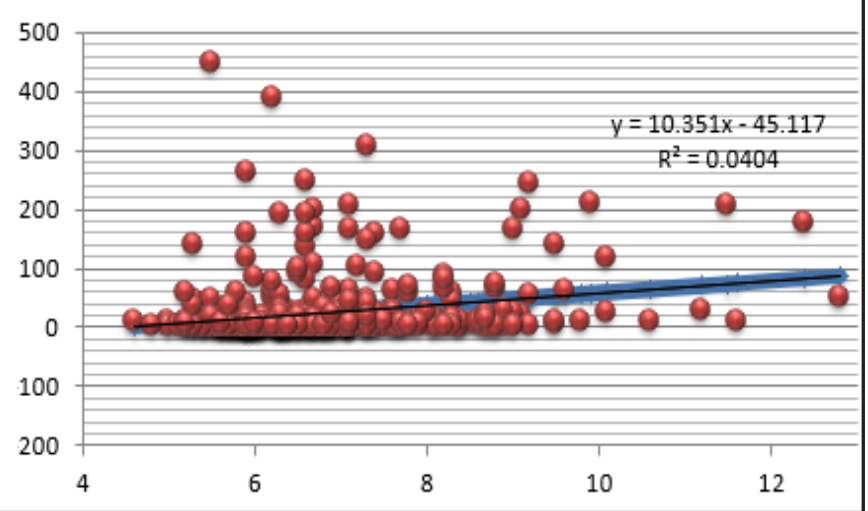

Fig. 3. Correlation between $\mathrm{HbAlc}$ and albumin glomerular excretion in type 2 diabetes mellitus patients

In our study the prevalence of microalbuminuria defined as an album/creatinine ratio $>30 \mathrm{mg} / \mathrm{g}$ but $<300 \mathrm{mg} / \mathrm{g}$ in urine spot was $16.14 \%$. The mean duration of diabetes mellitus in our study was 5.38 years. In a cross-sectional study on a population of similar race the prevalence of microalbuminuria was lower than in our study $10.1 \%$ [ 18]. The same study indicated that race is an important risk factor for microalbuminuria in type 2 diabetes mellitus patients, its prevalence in a comparative cohort of Asian ethnicity was $30.7 \%$ [ 18]. The duration of diabetes mellitus significantly influences the prevalence of microalbuminuria: in a group where the disease duration was greater than 15 years the prevalence of microalbuminuria was $100 \%$ [19]. In our study the diabetes duration in both groups, the patients with and without albuminuria, was almost similar and therefore disease duration did not impact the value of albumin/creatinine ratio. However, the striking aspect is that at similar disease durations one group has a mean albumin/creatinine ratio of $119.45 \mathrm{mg} / \mathrm{g}$ while the other has a mean albumin/creatinine ratio of $6.78 \mathrm{mg} /$ g. The explanation consists in the statistically significant 


\begin{tabular}{|c|c|c|c|}
\hline The possible influence factor & Coefficient & Standard Error & p-value \\
\hline Intercept & -112.34 & 52.05 & 0.0314 \\
\hline Age & -0.27 & 0.37 & 0.4717 \\
\hline Gender & -5.62 & 7.31 & 0.4424 \\
\hline GFR & -0.26 & 0.35 & 0.4541 \\
\hline HbA1c & 8.60 & 2.48 & 0.0006 \\
\hline BMI & 0.20 & 0.52 & 0.7089 \\
\hline Systolic blood pressure & 0.42 & 0.23 & 0.0415 \\
\hline Diastolic blood pressure & 1.25 & 0.40 & 0.0019 \\
\hline Total cholesterol & -0.30 & 0.26 & 0.2584 \\
\hline HDL-cholesterol & 0.03 & 0.37 & 0.9250 \\
\hline LDL-cholesterol & 0.12 & 0.29 & 0.6863 \\
\hline Triglycerides & 0.03 & 0.06 & 0.5881 \\
\hline
\end{tabular}

\begin{tabular}{|c|c|c|c|}
\hline The possible influence factor & Coefficient & Standard Error & p-value \\
\hline Intercept & 37.00 & 5.98 & 0.0000 \\
\hline ACEI or ARB & -17.28 & 6.07 & 0.0046 \\
\hline Spironolactone & -16.40 & 20.25 & 0.4183 \\
\hline Calcium channel blockers & 8.91 & 8.05 & 0.2689 \\
\hline Beta blockers & 13.65 & 8.35 & 0.1028 \\
\hline Diuretics & -7.95 & 6.94 & 0.2528 \\
\hline Statins & -7.37 & 5.81 & 0.1055 \\
\hline Niacin & -12.22 & 9.51 & 0.1995 \\
\hline Fibrates & -3.73 & 5.27 & 0.4801 \\
\hline Insulin therapy & -3.73 & 5.27 & 0.4801 \\
\hline
\end{tabular}

\begin{tabular}{|c|c|c|c|}
\hline The possible influence factor & Coefficient & Standard Error & p-value
\end{tabular}

\begin{tabular}{|c|c|c|c|}
\hline & & & \\
\hline Intercept & -71.53 & 53.40 & 0.1812 \\
\hline Age & -0.50 & 0.38 & 0.1892 \\
\hline Gender & -4.89 & 7.32 & 0.5042 \\
\hline GFR & -0.38 & 0.35 & 0.2822 \\
\hline HbA1c & 10.05 & 2.55 & 0.0001 \\
\hline BMI & 0.24 & 0.54 & 0.6537 \\
\hline Systolic blood pressure & 0.38 & 0.23 & 0.1025 \\
\hline Diastolic blood pressure & 1.16 & 0.40 & 0.0039 \\
\hline Total cholesterol & -0.36 & 0.26 & 0.1736 \\
\hline HDL-cholesterol & 0.17 & 0.36 & 0.6391 \\
\hline LDL-cholesterol & 0.12 & 0.29 & 0.6876 \\
\hline Triglycerides & 0.05 & 0.06 & 0.4240 \\
\hline ACEI or ARB & -14.61 & 6.00 & 0.0154 \\
\hline Spironolactone & -11.03 & 19.64 & 0.5747 \\
\hline Calcium channel blockers & 5.67 & 7.94 & 0.4758 \\
\hline Beta blockers & 16.00 & 8.11 & 0.1491 \\
\hline Diuretics & -7.42 & 6.88 & 0.2818 \\
\hline Statins & -12.30 & 6.29 & 0.0411 \\
\hline Niacin & -1.76 & 10.50 & 0.8669 \\
\hline Fibrates & -15.68 & 9.69 & 0.1065 \\
\hline Insulin therapy & -9.86 & 5.25 & 0.0610 \\
\hline
\end{tabular}

higher $\mathrm{HbAlc}$ in the first group compared with the second one $(7.34 \pm 1.57$ vs. $6.68 \pm 1.01, p<0.01)$. These results prove that a low glycemic control is associated with a high glomerular albumin excretion and therefore with endothelial dysfunction. Data from literature confirms the association of high values of HBAlc and high $\mathrm{HbAlc}$ variability with the presence of microalbuminuria [20]. In our study using simple linear regression, HbAlc was the factor that had the strongest influence on microalbuminuria.

The prevalence of hypertension was statistically significant higher in patients with microalbuminuria than in patients without microalbuminuria. In other study the same relationship was found confirming that the presence of hypertension in type 2 diabetes patients is an early sign of a generalized vascular dysfunction [21]. In the clinicalbiochemical model that we proposed for the prediction of
Table 2

MODEL 1: CLINICAL-BIOCHEMICAL MODEL FOR PREDICTION OF THE MICROALBUMINURIA

Table 3

MODEL 2: PHARMACOLOGICAL MODEL FOR PREDICTION OF THE MICROALBUMINURIA

Table 4

MODEL 3: INTEGRATIVE MODEL FOR PREDICTION OF THE MICROALBUMINURIA 
renal albumin excretion, which means that this therapy protects against the apparition of albuminuria in type 2 diabetes mellitus patients. Data from the scientific literature confirms that ACEI or ARB treatment has a renal protective effect and also reduces the cardiovascular morbidity and mortality [22]. In our study, compared with other studies [22] we can observe a low usage of ACEI or ARB treatment in the group of type 2 diabetes mellitus patients with microalbuminuria despite the high prevalence of hypertension in this group of $93.05 \%$. The impact of ACEI treatment in the health of patients with diabetes mellitus has been investigated in many studies. In the Collaborative Study Group, ACEl administered to a group of patients with type 1 diabetes mellitus determined the reduction of the risk of creatinine doubling, death, dialysis and kidney transplantation with more than $50 \%$ when compared with patients that did not receive ACEI treatment [23]. In the ADVANCE study, the administration of perindopril/ indapamide combination for a mean interval of 4.3 years determined the reduction of new onset microalbuminuria and prolonged the interval of progression to nephropathy [24]. Concerning ARB efficacy in renal protection, Irbesartan (an ARB) demonstrated a reduction of serum creatinine with $25-28 \%$ in type 2 diabetes patients when compared to placebo [25]. Olmesartan, another ARB, in the ROADMAP study, demonstrated a delayed progression to microalbuminuria of type 2 diabetes mellitus patients when compared to placebo [26]. These results should warn the physician about the need to optimize the treatment of hypertensive type 2 diabetes mellitus patients.

In the integrative model for the prediction of glomerular album excretion we identified 2 new factors that influence these parameters. Some of these factors were identified in the previous models, $\mathrm{HbAlc}$, diastolic blood pressure and ACEI or ARB treatment. One of these factors constitutes an unexpected finding, statin treatment. Dyslipidemia has a negative impact on the glomerular function generating glomerular and interstitial injury [27]. Statins have a proven capacity to decrease neutrophil and macrophage infiltration at the glomerular level, to reduce the renal cell proliferation and inflammatory cytokines [28]. There are few studies in the literature that analyze the effect of statin treatment on microalbuminuria. One of these studies reported that statins reduce the loss of glomerular filtration rate by $1.2 \mathrm{ml} / \mathrm{min} / \mathrm{year}$ [29]. Other study demonstrated that statin therapy is associated with a significant decrease of albumin excretion [30]. However, there are studies which conclude that statin therapy has no protective effect on renal function [31-33]. In our study beta blockers failed to demonstrate a protection against albuminuria despite reports that they have a beneficial effect [34]. Fibrates therapy also did not demonstrate any protection in our study despite data suggesting that they reduce microal buminuria [35].

Our study has the advantage to correlate the predictor elements with albuminuria including both patients with microalbuminuria and normo-albuminuria. More recent studies have shown that even normal levels of albumin excretion are associated with an increased cardiovascular risk in type 2 diabetes mellitus patients compared with patients that have no albuminuria; one study demonstrated a linear relationship between urinary albumin excretion and cardiovascular risk [36]. Patients with a urinary excretion of albumin between 1 to $2 \mu \mathrm{g} / \mathrm{min}$ had a statistically significant higher cardiovascular risk than patients with a urinary excretion of albumin $<1 \mu \mathrm{g} / \mathrm{min}$ [36]. These results highlight the importance of screening for albuminuria in diabetic patients. The screening is poorly achieved as reported by other studies where it was done only in one third of the diabetic patients and among the ones identified with positive microalbuminuria only $37 \%$ were under treatment with ACEI or ARB [37].

\section{Conclusions}

Risk factors for increased al buminuria in type 2 diabetes mellitus patients are a high $\mathrm{HbAlC}$ level and high blood pressure while protective factors for albuminuria are ACEI or ARB treatment and statins treatment. Treatment optimization in type 2 diabetes mellitus patients is important in order to decrease albuminuria which is a good marker for generalized endothelial dysfunction.

\section{References}

1.SATCHELL, S.C., TOOKE, J.E., Diabetologia, 51, nr. 5, 2008, p. 714. 2.J ENSEN, J.S., FELDT-RASMUSSEN, B., STRANDGAARD, S., SCHROLL, M., BORCH-JOHNSEN, K., Hypertension, 35, 2000, p. 898.

3.FODOR, K., TIT, D.M., PASCA, B., BUSTEA, C., UIVAROSAN, D., ENDRES, L., IOVAN, C., ABDEL-DAIM, M., BUNGAU S., Oxid. Med. Cell. Longev., 2018, 2018, ID 4147320, 10 pages. https://doi.org/10.1155/ 2018/4147320

4.PETERSEN, K.F., DUFOUR, S., BEFROY, D., GARCIA, R., SHULMAN, G.I., N. Engl. J. Med., 350, nr. 7, 2004, p. 664.

5.DIACONU, C.C., DRAGOI, C.M., BRATU, O.G., NEAGU, T.P., PANTEA STOIAN, A., COBELSCHI, P.C., NICOLAE, A.C., IANCU, M.A., HAINAROSIE, R., STANESCU, A.M.A., SOCEA, B., Farmacia, 2018, 66, nr. 3, 2018, p. 408.

6.DIACONU, C.C., MANEA, M., IANCU, M.A., STANESCU, A.M.A., SOCEA, B., SPINU, D.A., MARCU, D., BRATU, O.G., Rev. Chim. (Bucharest), 69, nr. 5, 2018, p. 1071

7.YUAN, C.M., NEE, R., CECKOWSKI, K.A., KNIGHT, K.R., ABBOTT, K.C., Clin. Kidney J., 10, nr. 2, 2016, p. 257.

8.KUMAR, V., ABBAS, A.K., FAUSTO N., et al. Robbins and Cotran Pathologic Basis of Disease, $9^{\text {th }}$ ed., Saunders, An Imprint of Elsevier, Philadelphia, Pennsylvania 19106, 2015, p. 991.

9.DIACONU, C.C., STANESCU, A.M.A., PANTEA STOIAN, A., TINCU, R.C., COBILINSCHI, C., DRAGOMIRESCU, R.I.F., SOCEA, B., SPINU, D.A., MARCU, D., SOCEA, L.I., BRATU, O.G., Rev. Chim. (Bucharest), 69, no. 6, 2018, p. 1367.

10.STOICESCU, M., CSEPENTO, C., MUTIU, G., BUNGAU, S., Rom. J. Morphol. Embriol., 52, nr. 1 Suppl., 2011, p. 419.

11.PASKO, N., TOTI, F., STRAKOSHA, A., et al., Hippokratia, 17, nr. 4, 2013, p. 337.

12.GABOR-HAROSA, F.M., STAN, O.P., DAINA, L., MOCEAN, F.,130, 2016, p. 198, doi: 10.1016/j.cmpb.2016.01.022.

13.XU, J., LEE, E.T., DEVEREUX, R.B., et al., Am. J. Kidney Dis.,51, nr. 3, 2008, p. 415.

14.BADEA, M., LUZARDO, O.P., GONZALEZ-ANTUNA, A., ZUMBADO, M., ROGOZEA, L., FLOROIAN, L., ALEXANDRESCU, D., MOGA, M., GAMAN, L., RADOI, M., BOADA, L.D., HENRIQUEZ-HERNANDEZ, L.A., Environ. Res., 166, 2018, p. 269.

15.DOUNOUSI, E., DUNI, A., LEIVADITIS, K., VAIOS, V., ELEFTHERIADIS, T., LIAKOPOULOS, V., Rev. Diab. Stud., 12, nr. 1-2, 2015, p. 119.

16.PARIJ AT, D., DAS G. HARLEY, K., NAIR, H., Br. J. Diabetes. Vasc. Dis., 6, 2006, p. 23.

17.CHAWLA, T., SHARMA, D., SINGH, A., World J. Diabet., 1, nr. 5, 2010, p. 141. doi:10.4239/wjd.v1.i5.141.

18.DIXON, A.N., RAYMOND, N.T., MUGHAL, S., RAHIM, A., O'HARE, J.P., KUMAR, S., BARNETT, A.H., Diab. Vasc. Dis. Res.,3, nr. 1, 2006, p. 22.

19.CHOWTA, N.K., PANT, P., CHOWTA, M.N., Indian J. Nephrol., 19, nr. 2, 2009, p. 53.

20.HSU, C.C., CHANG, H.Y., HUANG, M.C., HWANG, S.J ., YANG, Y.C., LEE, Y.S., SHIN, S.J ., TAI, T.Y., Diabetologia, 55, nr. 12, 2012, p. 3163. 
21.AFKHAMI-ARDEKANI, M., MODARRESI, M., AMIRCHAGHMAGHI, E., Indian J. Nephrol., 18, nr. 3, 2008, p. 112.

22.XIE, Q., HAO, C.M., JI, L., etal., PLoS One,10, nr. 2, 2015, p. e0116970. doi:10.1371/journal.pone.0116970

23.LEWIS, E.J., HUNSICKER, L.G., BAIN, R.P., ROHDE, R.D., N. Engl. J. Med., 329, nr. 20, 1993, p.1456.

24.DE GALAN, B.E., ZOUNGAS, S., CHALMERS, J., et al., Diabetologia, 52, nr. 11, 2009, p. 2328.

25.LEWIS, E.J., HUNSICKER, L.G., CLARKE, W.R., et al., N. Engl. J. Med., 345, nr. 12, 2001, p. 851.

26.HALLER, H., ITO, S., IZZO, J.L., et al., N. Engl. J. Med., 364, nr. 10, p. 907.

27.KEANE, W.F., Kidney Int., 75, 2000, p. S27.

28.NIKOLIC, D., BANACH, M., NIKFAR, S., SALARI, P., MIKHAILIDIS, D.P., TOTH, P.P., ABDOLLAHI, M., RAY, K.K., PENCINA, M.J ., MALYSZKO, J., RYSZ, J., RIZZO, M., Int. J. Cardiol., 168, nr. 6, 2013, p. 5437. 29.SANDHU, S., WIEBE, N., FRIED, L.F., TONELLI, M., J. Am. Soc. Nephrol., 17, 2006, p. 16.
30.SHEN, X., ZHANG, Z., ZHANG, X., et al., Lipids Health Dis., 15, nr. 1, 2016, p. 179. doi:10.1186/s12944-016-0350-0

31.PALMER, S.C., NAVANEETHAN, S.D., CRAIG, J.C., JOHNSON, D.W., PERKOVIC, V., HEGBRANT, J., STRIPPOLI, G.F., Cochrane Database Syst. Rev., 31, nr. 5, 2014, CD007784.

32.ABDEL-DAIM, M.M., ABO-EL-SOOUD, K., ALEYA, L., BUNGAU, S. G., NAJDA, A., SALUJA, R., Oxid. Med. Cell. Longev., 2018, 2018, ID 6276438. doi: $10.1155 / 2018 / 6276438$

33.ABDEL-DAIM, M.M., ZAKHARY, N.I., ALEYA, L., BUNGAU, S.G., BOHARA, R.A., SIDDIQI, N.J., Oxid. Med. Cell. Longev., 2018, 2018, ID 2098123. doi:10.1155/2018/2098123

34.J AWA, A., NACHIMUTHU, S., PENDERGRASS, M., ASNANI, S., FONSECA, V., J. Diabetes Complications, 22, nr. 5, 2008, p. 303.

35.ANSQUER, J.C., FOUCHER, C., RATTIER, S., et al., Am. J. Kidney Dis., 45, 2005, p. 485.

36.RUGGENENTI, P., PORRINI, E., MOTTERLINI, N., et al., J. Am. Soc. Nephrol., 23, nr. 10, 2012, p. 1717.

37.BOERO, R., PRODI, E., ELIA, F., PORTA, L., MARTELLI, S., FERRARO, L., QUARELLO, F., J. Hum. Hypertens., 17, nr. 6, 2003, p. 413.

$\overline{\text { Manuscript received: } 11.02 .2019}$ 